\title{
Alergia kontaktowa w zawodzie technika dentystycznego
}

\author{
Contact allergy in the occupation of a dental technician
}

Zakład Technik Dentystycznych i Zaburzeń Czynnościowych Narządu Żucia, Gdański Uniwersytet Medyczny

DOI: http://dx.doi.org/10.20883/df.2016.12

\begin{abstract}
Streszczenie
W pracy opisano problem występowania alergii kontaktowej u techników dentystycznych jako choroby zawodowej. Objawy alergii mogą utrudniać a nawet uniemożliwiać pracę w laboratorium. Omówiono główne alergeny wziewne i kontaktowe: metakrylan metylu oraz pierwiastki składowe stopów metali i stali stosowanych w laboratorium techniki dentystycznej. Zwrócono uwagę na możliwości ograniczenia ekspozycji na substancje uczulające poprzez używanie środków ochrony osobistej lub zastosowanie alternatywnych materiałów i metod w wykonawstwie uzupełnień protetycznych i ortodontycznych. Podniesienie świadomości narażenia na alergeny kontaktowe może przyczynić się do zmniejszenia występowania objawów alergii oraz wzrostu wydajności pracy techników dentystycznych.
\end{abstract}

Słowa kluczowe: alergia kontaktowa, technik dentystyczny, metakrylany metylu, stopy metali.

\begin{abstract}
This article shows the prevalence of contact allergy in dental technicians as an occupational disease. Allergy symptoms can make it difficult or even impossible to work in the laboratory. The main airborne and contact allergens were described: methyl methacrylate, dental alloys and steel ingredients used in the dental laboratory. Attention was paid to limiting the exposure to allergic substances through using personal protective equipment or alternative materials and methods when producing dental prostheses or removable braces. Raising awareness with regard to exposure to contact allergens may help to reduce the allergy symptoms and increase the efficiency of dental technicians' work.
\end{abstract}

Keywords: contact allergy, dental technician, methylmethacrylates, dental alloys.

\section{Wstęp}

Zawód technika dentystycznego wymaga stałego kontaktu z materiałami będącymi potencjalnym źródłem alergenów wziewnych i kontaktowych. Należą do nich tworzywa akrylanowe, stopy metali zawierające w składzie nikiel, chrom, kobalt, złoto, a także pary i pyły powstające podczas przygotowywania lub obróbki materiałów. Nawet niewielka reakcja immunologiczna pod wpływem stałej ekspozycji może z czasem prowadzić do powstania procesu chorobowego utrudniającego lub uniemożliwiającego pracę w laboratorium. Celem niniejszej pracy jest ukazanie problemu występowania alergii kontaktowej w pracy technika dentystycznego oraz możliwości zmniejszenia prawdopodobieństwa pojawienia się objawów.

\section{Metody przeglądu}

Przeglądu piśmiennictwa dokonano w oparciu o internetowe bazy naukowych czasopism recenzowanych z wykorzystaniem słów kluczowych: alergia kontaktowa (contact allergy), technik dentystyczny (dental technician), metakrylan metylu (methyl methacrylate), nikiel (nikel), narażenie zawodowe (occupational exposure), lateks (latex), złoto (gold). Prace w języku polskim wyszukano w bazie czasopism Polska Bibliografia Lekarska.
W opracowaniu tematu wzięto pod uwagę objawy i występowanie alergii kontaktowej w zawodzie technika dentystycznego oraz narażenie zawodowe wynikające $z$ kontaktu $z$ alergenami, takimi jak metakrylan metylu czy metale nieszlachetne i szlachetne. Uwzględniono również informacje na temat diagnostyki i ochrony przed substancjami alergizującymi w celu zmniejszenia lub wyeliminowania ich negatywnego wpływu w pracy technika dentystycznego.

\section{Objawy i występowanie alergii kontaktowej}

Alergia kontaktowa to swoista nadwrażliwość organizmu wynikająca $z$ ekspozycji na substancje chemiczne o małej masie cząsteczkowej (hapteny) oraz proteiny. Przeciwciała nie biorą prawdopodobnie udziału $w$ tej reakcji, co odróżnia alergię kontaktową od innych typów reakcji alergicznych [1]. Najczęstszym objawem narządowym alergii kontaktowej jest alergiczne kontaktowe zapalenie skóry, choć zdarzają się objawy w obrębie jamy ustnej czy spojówek.

Alergiczne kontaktowe zapalenie skóry cechuje się występowaniem wykwitów skórnych, które wraz z zaawansowaniem procesu chorobowego zanikają lub podlegają przemianom z równoczesnym powstawaniem wykwitów wtórnych. Podtrzy- 
manie kontaktu $z$ alergenem powoduje przejście ostrego stanu zapalnego w przewlekły oraz pojawianie się nowych ognisk chorobowych w innych okolicach ciała jako wtórnego efektu uczulenia [1]. Alergiczne kontaktowe zapalenie skóry znajduje się na liście chorób zawodowych.

Alergia kontaktowa w stosunku do co najmniej jednego alergenu dotyczy $27 \%$ europejskiej populacji ludzi dorosłych [2]. Wśród badanych z wziewną alergią kontaktową 35\% przypadków choroby było związanych z wykonywanym zawodem [3]. W badaniach epidemiologicznych nad częstością występowania chorób atopowych w Polsce (PMSEAD), przeprowadzonych u 16238 osób stanowiących grupę reprezentatywną mieszkańców Polski, alergiczne kontaktowe zapalenie skóry stwierdzono u 2\% osób [4]. Brakuje badań określających ogólny odsetek chorych w grupie zawodowej techników dentystycznych. $\mathrm{Na} 106$ zbadanych techników dentystycznych w 1984 r. w Helsinkach w Finlandii, 30 podało pojawienie się zmian skórnych w przeszłości lub teraźniejszości. Spośród tych osób 19 wiązało objawy z wykonywaną pracą a 11 wskazało kontakt z tworzywem akrylanowym jako potencjalną przyczynę objawów. Jedynie 4 techników miało alergię kontaktową potwierdzoną za pomocą testów [5]. Rustemeyer i Frosch przebadali 55 techników dentystycznych, którzy stwierdzili występowanie zmian skórnych związanych z wykonywanym zawodem. Okazało się, że 63,6\% tych zmian miało charakter alergiczny [6].

\section{Narażenie na metakrylan metylu}

Tworzywo akrylanowe stosowane w stomatologii m.in. do wykonania protez częściowych i całkowitych, szyn relaksacyjnych oraz ruchomych aparatów ortodontycznych jest jedną z częściej wymienianych substancji uczulających.

Za główny czynnik alergiczny tworzyw akrylanowych uważany jest monomer [7]. W technice dentystycznej najczęściej stosowany jest metakrylan metylu $\left(\mathrm{C}_{5} \mathrm{H}_{8} \mathrm{O}_{2}\right)$, który jest lotną cieczą o ostrym, nieprzyjemnym zapachu, działającą przede wszystkim drażniąco i alergizująco [8]. Badania Bereznowskiego przeprowadzone wśród techników z długoletnim stażem pracy negują działanie toksyczne na narządy wewnętrzne metakrylanu metylu ulatniającego się podczas przygotowywania tworzywa akrylanowego [9]. Kanazawa i wsp. wykazali, że potencjał alergizujący metakrylanów wzrasta wraz z wydłużaniem się łańcucha węglowego i jest największy dla cząsteczek od $\mathrm{C}_{1}$ do $\mathrm{C}_{12}$, a następnie maleje [10]. Długotrwała ekspozycja, która ma miejsce w laboratorium techniki dentystycznej, może powodować podrażnienia nabłonka układu oddechowego, spojówek oczu oraz skóry. Udowodniono, że występowanie stanów chorobowych na skórze może wynikać z podrażnienia działaniem wysokiej temperatury, tarcia mechanicznego i wilgoci w środowisku pracy, bez kontaktu z substancją alergizującą [11]. Jednak zniszczenie zewnętrznej bariery ochronnej nabłonka lub naskórka może być przyczyną większej podatności na powstanie zarówno wziewnej alergii, jak i alergii kontaktowej.

Metakrylan po wchłonięciu przez nabłonek lub skórę jest metabolizowany do kwasu metakrylowego, a następnie do dwutlenku węgla i wody. Metakrylan metylu, który nie został zmetabolizowany do dwutlenku węgla ani wydalony, trafia przede wszystkim do wątroby i tkanki tłuszczowej, chociaż niewielkie jego ilości mogą się również znaleźć w mózgu i płucach [12].

Przygotowanie tworzywa akrylanowego do polimeryzacji polega na zmieszaniu płynnego monomeru z proszkiem. W przypadku polimeryzacji termicznej otrzymaną masę akrylanową upycha się do puszki polimeryzacyjnej i poddaje działaniu wysokiej temperatury. Tworzywa akrylanowe chemoutwardzalne polimeryzują $w$ temperaturze pokojowej a światłoutwardzalne pod wpływem lampy UV. Zaremba i wsp. twierdzą, że w czasie trwania reakcji polimeryzacji maleje zdolność inicjatorów do przeprowadzenia reakcji chemicznej [13]. Całkowita polimeryzacja materiału nie jest zatem możliwa, część grup metakrylanowych nie ulega reakcji i pozostaje jako wolny monomer. W przypadku polimeryzacji chemicznej obserwuje się najwyższą wartość monomeru resztkowego sięgającą 4\% [14]. Już niewielka ilość monomeru uwalniająca się w postaci monomeru resztkowego może wywołać reakcję alergiczną [15].

Specyfika pracy z tworzywem akrylanowym na ogół we wszystkich przypadkach wymaga kontaktu ze skórą dłoni technika dentystycznego i tym samym wzrasta ryzyko alergizacji. Ponadto podczas procesu polimeryzacji tworzywa akrylanowego dochodzi do wzrostu temperatury i większego prawdopodobieństwa uszkodzenia naskórka, co może wpływać na obniżenie progu wrażliwości na alergen.

Najbezpieczniejszym sposobem polimeryzacji tworzywa akrylanowego jest używanie urządzenia wtryskowego. Tworzywo o fabrycznie dobranych proporcjach polimeru i monomeru znajduje się w jednorazowych kapsułach, które miesza się automatycznie w wibratorze a następnie wtłacza do formy pod ciśnieniem. Taki przebieg procesu pozwala na uzyskanie bardziej homogennego materiału pozbawionego monomeru resztkowego oraz wyeliminowanie wdychania par monomeru, jak i kontaktu tworzywa ze skórą dłoni.

Narażenie na wystąpienie alergii kontaktowej oraz wziewnej występuje podczas obróbki mechanicznej tworzywa akrylanowego. Pyły znajdujące się w powietrzu mogą przyczynić się do powstania alergii wziewnej, a bezpośredni kontakt skóry dłoni ze spolimeryzowanym materiałem podnosi ryzyko uczulenia na monomer resztkowy. 
W celu ochrony przed parami monomeru należy stosować maseczki i okulary ochronne oraz wentylować pomieszczenie podczas pracy. Świdwińska-Gajewska i Kupczewska-Dobecka podają, że najwyższe dopuszczalne stężenie w środowisku pracy NDS metakrylanu metylu wynosi 50 $\mathrm{mg} / \mathrm{m}^{3}[8]$. W bezpośrednim kontakcie skóry dłoni z tworzywem należy stosować rękawice odporne na działanie rozpuszczalników organicznych oraz nie wolno spożywać podczas pracy napojów ani pokarmów.

Badania Munksgaard [16] oraz Andersson i wsp. [17] wskazują na brak ochronnej roli rękawiczek lateksowych przed działaniem monomerów. Mikov i wsp. opisali przypadek 28-letniej pacjentki wykonującej zawód technika dentystycznego, która skarżyła się na zaczerwienienie, szczypanie i pękanie skóry dłoni. Objawy zmniejszały się w dni wolne od pracy. Testy wykazały nadwrażliwość na metakrylan metylu, który przenikał nawet przez rękawiczki ochronne, w których pacjentka wykonywała prace protetyczne. Po 6 tygodniach unikania alergenu objawy całkowicie ustapiły [18]. Inne badania pokazują, że same rękawiczki lateksowe mogą być czynnikiem alergizującym. Technicy używają rękawiczek ochronnych szczególnie podczas kontaktu skóry dłoni z wyciskami, wzornikami woskowymi lub innymi elementami protetycznymi przebywającymi w jamie ustnej pacjenta celem ochrony przed czynnikami biologicznymi. Ze względu na potencjalną alergię kontaktową na lateks powinni rozważyć stosowanie innych rękawiczek ochronnych, np. nitrylowych.

\section{Narażenie na stopy metali}

Kolejnym czynnikiem potencjalnej alergii kontaktowej są metale. W praktyce laboratoryjnej używa się około 40 pierwiastków metalicznych, które są składnikami stopów dentystycznych wykorzystywanych w wykonawstwie uzupełnień protetycznych, jak i do produkcji narzędzi. Wśród pierwiastków mogących wywołać odczyny alergiczne wymienia się nikiel, chrom, kobalt, pallad, srebro i miedź. Ich pary i pyły powstające podczas procesów odlewniczych i obróbki mechanicznej są wdychane przez techników dentystycznych i mogą być przyczyną wziewnej alergii lub alergii kontaktowej powstającej na skutek pracy ze stopami metali.

Narzędzia stosowane do modelowania uzupełnień protetycznych są wykonane ze stali nierdzewnej, której pierwowzorem jest stal Wipla. Współczesne stale posiadają zbliżony skład i zawierają: $72-74 \%$ żelaza, $18-20 \%$ chromu, 8-10\% niklu, $0,02-0,08 \%$ węgla oraz niewielkie dodatki substancji stabilizujących. Nikiel stabilizuje strukturę stali [14]. Podobnie jak narzędzia, ze stali wykonywany jest jest drut dentystyczny. Jest on doginany ręcznie przez techników dentystycznych do postaci klamer i łuków podczas wykonywania aparatów ortodontycznych oraz protez zębowych.
Kettelarij i wsp. przeprowadzili doświadczenie, w którym w roztworze sztucznego potu umieścili narzędzia i stopy metali pochodzące z laboratorium techniki dentystycznej. Stwierdzili uwalnianie się z narzędzi alergizujących metali, takich jak kobalt, nikiel i chrom, w ilości: Co $0.0047-820$, Ni 0.0051-10, Cr 0.010-160 $\mu \mathrm{g} / \mathrm{cm}^{2} /$ tydzień, natomiast stężenie uwolnionych metali ze stopów było niższe i nie przekroczyło $17 \mu \mathrm{g} / \mathrm{cm}^{2} /$ tydzień [19]. Obraz kliniczny alergii na nikiel jest typowy dla kontaktowego alergicznego zapalenia skóry. Zdarzają się jednak zmiany skórne uogólnione, zwłaszcza w wyniku kontaktu cząsteczek niklu unoszących się w powietrzu podczas obróbki mechanicznej materiału [20]. Według badań Bajaj i wsp. na wystąpienie uczulenia na nikiel bardziej narażone są kobiety palące niż niepalące, czego nie zaobserwowano u mężczyzn [21]. Badania Bonamonte i wsp. ukazują wpływ stężenia hormonów w poszczególnych fazach cyklu menstruacyjnego kobiet na obniżenie lub nasilenie objawów alergii kontaktowej na nikiel [22]. Nawet zaburzenie metabolizmu żelaza $w$ postaci obniżenia poziomu w surowicy krwi może mieć związek z wystąpieniem alergii na nikiel [23].

Najczęściej dotąd stosowane przez techników dentystycznych stopy metali to stopy niklowo-chromowe, kobaltowo-chromowe oraz stopy złota. Dostępne na rynku stopy niklowo-chromowe zawierają przeciętnie $61-77 \%$ niklu, $12-26 \%$ chromu, 3-11\% molibdenu i do 2\% krzemu. Wprowadzenie Dyrektywy 94/27/WE w Unii Europejskiej obowiązującej od 2001 r. spowodowało stopniowe odchodzenie od stosowania tego stopu w laboratorium techniki dentystycznej. Jest on w dużej mierze zastępowany przez stop kobaltowo-chromowy, który w swoim składzie posiada około $64 \%$ kobaltu, $29 \%$ chromu oraz $5 \%$ molibdenu (Wironit).

Alergia na kobalt zwykle współistnieje z uczuleniem na chrom u mężczyzn i nikiel u kobiet [24]. Być może jest to spowodowane reakcjami krzyżowymi w obrębie metali. Badania Lisi i wsp. wskazują jednak na uczulenie współistniejące, wynikające $z$ łącznej ekspozycji na różne metale [25].

Z obróbką metali wiąże się również polerowanie elektrolityczne. Elektrolit jest mieszaniną glikolu etylenowego, kwasu siarkowego i solnego, a kontakt z nim może powodować reakcje alergiczne.

Metalem stosowanym w protetyce najdłużej jest złoto. Stopy złota zawierają inne metale poprawiające ich właściwości mechaniczne i odlewnicze. Skład stopów o dużej zawartości złota opiera się na proporcjach opracowanych wiele lat temu, według których powinny one zawierać $75 \%$ złota i metali z grupy platynowców: platyny, palladu, irydu, rodu, rutenu, osmu. Pozostałe metale: miedź, srebro, gal, nikiel, tytan, cynk, ind oraz żelazo dodawane są w ilości do $25 \%$ i stanowią dodatki stopowe [26]. Powszechnie uważa się, że ograniczenie stosowania stopów metali na rzecz 
stopów złota, które jest oceniane jako biokompatybilne, a nawet ma działanie bakteriostatyczne, mogłoby zmniejszyć częstość występowania alergii kontaktowej u techników dentystycznych. Niestety opisano wiele przypadków alergii na złoto i jego sole [27, 28]. Liczne publikacje dotyczące toksyczności metali, nie wyłączając złota, skłaniają do ostrożniejszego postępowania z metalami, gdyż pomijając stomatologiczny aspekt, problem alergii sukcesywnie rośnie.

Kim i wsp. zdiagnozowali zapalenie płuc u kobiety, która od 10 lat pracowała jako technik dentystyczny a od roku cierpiała z powodu chronicznego kaszlu oraz duszności podczas wchodzenia po schodach. Badania laboratoryjne, radiologiczne oraz histologiczne pozwoliły zdiagnozować zapalenie płuc $z$ nadwrażliwości. W pracy pacjentka narażona była na pyły metali oraz metakrylan metylu. Po 2 miesiącach od diagnozy i rezygnacji z pracy objawy ustąpiły [29].

\section{Diagnostyka}

Diagnostyka alergicznego kontaktowego zapalenia skóry powinna opierać się na wnikliwym wywiadzie lekarskim uwzględniającym przebieg choroby i okoliczności powstania zmian, czyli rodzaj wykonywanej pracy, warunki pracy i mieszkania, upodobania, stosowaną dietę i leki.

Metodą z wyboru pomocną w diagnostyce alergicznego kontaktowego zapalenia skóry jest test płatkowy, który polega na wywołaniu zmian skórnych w ściśle kontrolowanych warunkach. Nasilenie miejscowej, prowokowanej reakcji zapalnej wskazuje na istnienie nadwrażliwości organizmu na badany alergen. Bardziej czułym testem jest test śródskórny, który pozwala na szybsze rozpoznanie alergii kontaktowej [1].

\section{Wnioski}

Diagnostyka i leczenie alergii kontaktowej oraz unikanie kontaktu $\mathrm{z}$ alergenem poprzez wybór alternatywnych materiałów i metod stosowanych w technice dentystycznej, a także stosowanie środków ochrony podczas pracy wydaje się być ważnym czynnikiem w zmniejszeniu objawów alergii. Mimo wprowadzenia materiałów zastępczych dla polimetakrylanu metylu, takich jak acetal czy nylon, tworzywo akrylanowe, ze względu na swoje właściwości mechaniczne i fizyczne, pozostaje jak dotąd głównym tworzywem wykorzystywanym w wykonawstwie protez płytowych.

Kontynuacja pracy jest możliwa pod warunkiem zapewnienia odpowiedniej wentylacji pomieszczenia, w którym wykonywana jest praca, a także stosowania wody przy obróbce mechanicznej dla zmniejszenia stężenia pyłów w powietrzu. Celowe wydaje się przeprowadzenie badań na temat świadomości ograniczenia objawów alergii wśród techników dentystycznych.

\section{Oświadczenia}

Oświadczenie dotyczące konfliktu interesów

Autorzy deklarują brak konfliktu interesów w autorstwie oraz publikacji pracy.

\section{Źródła finansowania}

Autorzy deklarują brak źródeł finansowania.

\section{Piśmiennictwo}

[1] Śpiewak R. Alergia kontaktowa - diagnostyka i postępowanie. Alerg Astma Immun. 2007;3:109-127.

[2] Diepgen TL, Ofenloch RF, Bruze M, Bertuccio P, Cazzaniga S, Coenraads PJ i wsp. Prevalence of contact allergy in the general population in different European regions. Br J Dermatol. 2015. doi: 10.1111/bjd.14167.

[3] Breuer K, Uter W, Geier J. Epidemiological data on airborne contact dermatitis - results of the IVDK. Contact Dermatitis. 2015;73(4):239-247.

[4] Liebhart J, Dobek R, Małolepszy J, Wojtyniak B, Pisiewicz K, Płusa T i wsp. The prevalence of allergic diseases in Poland - the results of the PMSEAD study in relation to gender differences. Adv Clin Exp Med. 2014;23(5):757762.

[5] Estlander T, Rajaniemi R, Jolanki R. Hand Dermatitis in dental technicians. Contact Dermatitis. 1984;10:201-205.

[6] Rustemeyer T, Frosch PJ. Occupation skin diseases in dental labolatory technicians. Clinical picture and causative factors. Contact Dermatitis. 1996;34(2):125-133.

[7] Spiechowicz E. Protetyka Stomatologiczna. Wyd. Lek. PZWL, Warszawa 2010.

[8] Świdwińska-Gajewska A, Kupczewska-Dobecka M. Metakrylan metylu. Dokumentacja dopuszczalnych wielkości narażenia zawodowego. Podstawy i Metody Oceny Środowiska Pracy. 2009;3(61):127-158.

[9] Bereznowski Z. Uwalnianie się metakrylanu metylu z protez zębowych - jego metabolizm w tkankach zwierzęcych i ludzkich oraz efekty toksyczne in vitro. Czas Stom. 2000;53:572-579.

[10] Kanazawa Y,Yoshida T, Mojima K. Structure-activity relationship in allergic contact dermatitis induced by methacrylates. Contact Dermatitis. 1999;40(1):19-23.

[11] Lewczuk E, Affelska-Jercha A, Tomczyk J. Zawodowe zagrożenia zdrowotne $\mathrm{w}$ gabinetach stomatologicznych. Med Pracy. 2002;53(2):161-165.

[12] Raje RR, Ahmad S, Weisbroth SH. Methyl methacrylate: tissue distribution and pulmonary damage in rats following acute inhalation. Res Commun Chem Pathol Pharmacol. 1985;50:151-154.

[13] Zaremba J, Kieć-Świerczyńska M, Kręcisz B, Świerczyńska-Machura D. Tworzywa akrylanowe jako istotne źródła alergii kontaktowej pochodzenia zawodowego i pozazawodowego. Med Pracy. 2004;55(4):357-361.

[14] Majewski S, Pryliński M. Materiały i technologie. Wyd. Czelej. 2013;12:131-132.

[15] Drucker AM, Pratt MD. Acrylate contact allergy: patient characteristics and evaluation of screening allergens. Dermatitis. 2011;22(2):98-101.

[16] Munksgaard EC. Permeability of protective gloves to (di) methacrylates in resinous dental materials. Scand J Dent Res. 1992;100(3):189-192.

[17] Andersson T, Bruze M, Björkner B. In vivo testing of the protection of gloves against acrylates in dentin-bonding systems on patients with known contakt allergy to acrylates. Contact Dermatitis. 1999;41(5):254-259.

[18] Mikov I, Turkalj I, Jovanović M. Occupational contact allergic dermatitis in dentistry. Vojnosanit Pregl. 2011;68(6):523-525.

[19] Gembka K, Cichocka-Jarosz E. Alergia na lateks - czynniki wywołujące, symptomatologia i postępowanie. Alerg Astma Immun. 2013;18(3):151-163.

[20] Kettelarij JA, Lidén C, Axén E, Julander A. Cobalt, nickel and chromium release from dental tools and alloys. Contact Dermatitis. 2014;70(1):3-10. 
[21] Santos R, Goossens A. An update on airbone contact dermatitis: 2001-2006. Contact Dermatitis. 2007;57(6):353360.

[22] Bajaj AK, Saraswat A, Mukhija G. Patch testing experience with 1000 patients. Indian J Dermatol Venerol Lepr. 2007;73:313-318.

[23] Bonamonte D, Foti C, Antelmi AR, Biscozzi AM, Naro ED, Fanell M. Nickel contact allergy and menstrual cycle. Contact Dermatitis. 2005;52:309-313.

[24] Karaś Z. Skórny test płatkowy z siarczynem niklu - próba szerszej interpretacji uzyskiwanych wyników. Pol Merkuriusz Lek. 2002;74:143-146.

[25] Craig RG, Powers JM, Wataha JC. Materiały stomatologiczne Wyd. Med. Urban\&Partner, Wrocław 2000.

[26] Kieć-Świerczyńska M. Alergiczne kontaktowe zapalenie skóry. Uczulenie na metale cz. 1. Alergia. 2009;3:5-10.

[27] Lisi P, Brunelli L, Stingeni L. Co-sensivity between cobalt and other transition metals. Contact Dermatitis. 2003;48:172-173.

[28] Pietruski JK, Pietruska MD. Materiały i technologie używane we współczesnej protetyce stałych uzupełnień zębowych - wady i zalety przedstawione na podstawie przeglądu piśmiennictwa i doświadczeń własnych. Stomatologia Estetyczna. 2013;9(3):89-99.
[29] Giorgini S, Tognetti L, Zanieri F, Lotti T. Occupational Airborne Allergic Contact Dermatitis Caused by Gold. Am Contact Dermatitis Society. 2010;21(5):284-287.

[30] Möller H. Dental gold alloys and contact allergy. Contact Dermatitis. 2002;47:63-66.

[31] Kim YH, Chung YK, Kim C, Nam ES, Kim HJ, Joo Y. A case of hypersensitivity pneumonitis with giant cells in a female dental technician. Ann Occup Environ Med. 2013;25(1):19.

Zaakceptowano do edycji: 2016-04-28 Zaakceptowano do publikacji: 2016-05-06

\section{Adres do korespondencji:}

Anna Wytrykowska

ul. Tuwima 15, 80-210 Gdańsk

tel.: 583491235

e-mail: awytrykowska@gumed.edu.pl 